\title{
Structured Catalysts for Soot Combustion for Diesel Engines
}

\author{
E.D. Banús, M.A. Ulla, E.E. Miró and V.G. Milt
}

Additional information is available at the end of the chapter

http://dx.doi.org/10.5772/54516

\section{Introduction}

During the last decade, diesel engines have increased in popularity compared to gasoline engines because of their superior fuel economy, reliability and durability, simultaneously associated with a favorable fuel tax situation in several countries. At present, around $60 \%$ of all new European cars are equipped with diesel engines [1,2]. However, the emission from this kind of engines includes important contaminants, nitrogen oxides $\left(\mathrm{NO}_{\mathrm{x}}\right)$ and particulate matter (PM) being the ones of major concern. PM consists mostly of carbonaceous soot and a soluble organic fraction (SOF) of hydrocarbons condensed on the soot. Both PM and nitric oxides are known harmful compounds that affect human health and produce acid rain and photochemical smog, causing severe environmental problems.

The heterogeneity in the composition of the diesel fuel and air mixture in the combustion chamber of a diesel engine produces a great number of problems related to contaminant emissions. At the moment of the fuel injection, three regions can be distinguished in the cylinder: i) A region close to the injector, where the concentration of diesel fuel is relatively high; ii) The central region of the cylinder, where conditions are close to the stoichiometric ones; and iii) The most separated region from the injector, where the fuel concentration is low. If the generated turbulence is not enough in the first region, in the proximities of fuel drops there would not be sufficient oxygen to complete the fuel combustion. This leads to the formation of particulate matter (PM), which constitutes the typical black smoke observed from diesel vehicles during high acceleration or when they are cold. In contrast, in the third region, the oxygen excess and the very high temperature cause the appearance of important $\mathrm{NO}_{x}$ quantities. In the intermediate region, the diesel fuel/air ratio is close to the stoichiometric one so that the combustion is produced under near ideal conditions.

As previously said, PM is produced mainly close to the injector, in the areas where the fuel/air ratio is significantly high. Its formation involves four fundamental steps (Figure 1) [3]. 
1. Pyrolysis: A high concentration of fuel at high temperatures provokes that the fuel organic compounds alter their molecular structure without significant oxidation, although some oxygen may be present in the structure of the formed species. These molecules, such as $\mathrm{C}_{2} \mathrm{H}_{2}$, benzene and polycyclic aromatic hydrocarbons (PAHs) are called PM precursors.

2. Nucleation: Germs or nuclei of the PM primary particles are formed by arrangement of those precursors.

3. Surface growing: Primary particles are formed by a process of adding mass to the surface of a nucleated soot particle.

4. Coalescence and agglomeration: The combination of primary particles produces agglomerates, which are bigger particles than primary ones. During this process, from a greater number of small particles a smaller number of bigger particles are formed.

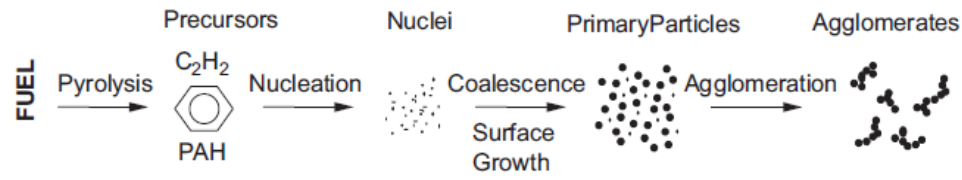

Figure 1. Steps involved in the formation of particulate matter (PM).

The PM composition depends on both the fuel quality and the heterogeneity of the combustion process occurring in the diesel engine. The PM is mostly composed of carbon, metal compound ashes and heavy organic compounds (soot), having adsorbed unburned hydrocarbons and condensed sulfates (SOF) on its surface.

The nitrogen oxides of the polluting emission gases are formed fundamentally at high temperatures in the low fuel/air ratio regions of the combustion chamber. These oxides are mainly nitric oxide (NO) and nitrogen dioxide $\left(\mathrm{NO}_{2}\right)$, and are collectively called $\mathrm{NO}$.

The $\mathrm{NO}_{\mathrm{x}}$ generation during combustion processes can take place through three different reaction paths, which have unique characteristics [4]:

1. Thermal NOx: The reaction between atmospheric nitrogen and oxygen at high temperatures produces $\mathrm{NO}_{x}$. The typical mechanism of this reaction was established by Zeldovich in 1946. The proposed mechanism involves a chain reaction of $\mathrm{O}^{*}$ and $\mathrm{N}^{*}$ activated atoms, $\mathrm{NO}$ being the final product. The conversion of $\mathrm{NO}$ to nitrogen dioxide $\left(\mathrm{NO}_{2}\right)$ occurs at low temperatures when exhaust gases are vented to the atmosphere.

2. Fuel $\mathrm{NO}_{x}$ : Fuel-bound nitrogen (FBN) is the source of $\mathrm{NO}_{x}$ emissions from combustion of nitrogen-bearing fuels such as heavy oils. FBN is converted to fixed nitrogen compounds such as $\mathrm{HCN}$ and $\mathrm{NH}_{3}$ in the reducing region of the engine (high fuel/air ratio zone). And then, the latter compounds are oxidized to $\mathrm{NO}_{x}$ in the low fuel/air ratio region.

3. Prompt $\mathrm{NO}_{x}$ : In the fuel-rich region, atmospheric nitrogen can react with different hydrocarbon fragments $\left(\mathrm{C}, \mathrm{CH}, \mathrm{CH}_{2}\right)$, producing nitrogen containing intermediate species $\left(\mathrm{NH}, \mathrm{HCN}, \mathrm{H}_{2} \mathrm{CN}, \mathrm{CN}\right)$. Then, these species react with $\mathrm{O}_{2}$ in the low fuel/air 
ratio region. The prompt mechanism is responsible for only a small fraction of the total $\mathrm{NOx}$.

Legislations related to the control of pollutants emission are becoming more severe; therefore, industrial R\&D departments and research groups face serious challenges to meet the specific emission requirements of future regulations. These days, most car manufacturers consider that a combination of catalysts and soot traps is the best approach to find a sustainable control of both $\mathrm{NO}_{\mathrm{x}}$ and soot emissions [2].

The combination of a filter with oxidation catalysts is the most widely studied after treatment process to eliminate soot particles. For $\mathrm{NO}_{x}$ abatement, adsorbers (traps) and SCR with ammonia or hydrocarbons constitute technologies both for partial lean-burn gasoline engines and for diesel ones. The adsorber (usually containing $\mathrm{Ba}$ or $\mathrm{K}$ compounds) chemically binds nitrogen oxide during lean engine operation. After the adsorber capacity is saturated, the system is regenerated and released $\mathrm{NO}_{\mathrm{x}}$ is reduced during a period of rich operation. In the case of diesel engines, since a rich operation is not feasible, periodic fuel injections are necessary [1].

\section{Emission control}

For diesel fuel, low volatility and excellent ignitability make it difficult to broaden the engine load range and optimize engine thermal efficiency. In the light of increasingly stringent diesel emission limits, changes in conventional combustion mode, addition of active elements to the fuel or after treatment of exhaust gases are needed. Concerning changes in combustion mode, even though considerable progress has been made in this research field over the last decade, the large scale adoption of HCCI (Homogeneous Charge Compression Ignition) diesel engines in commercial vehicles is currently not possible. The main challenges facing HCCI diesel engines are their limited operational range, lack of direct control of combustion phasing and increased $\mathrm{HC}$ and $\mathrm{CO}$ emissions, as reported in some applications [5,6]. Taking into account the addition of additives to the diesel fuel, cerium-based compounds have been used in order to lower PM emissions and to enhance oxidation rates but engine tests have shown an insensitive effect on gaseous pollutant emissions ( $\mathrm{HC}, \mathrm{CO}$ and $\mathrm{NO}_{\mathrm{x}}$ ).

Improvements in diesel engine designs will not be enough to meet the requirements of future legislation for both soot and $\mathrm{NO}_{\mathrm{x}}$. Therefore, after-treatment technologies are the object of intense research efforts. A variety of technologies have been proposed to abate $N \mathrm{x}_{\mathrm{x}}$ and soot; the combination of filters and combustion catalysts for particle removal and catalytic traps for nitric oxide reduction are among the most extensively investigated alternatives.

The main concern for the application of filters to remove soot particles is the regeneration step. Both thermal and mechanical methods must be ruled out due to either their inefficiency or inapplicability. The most widely studied way to conduct the regeneration is using filters combined with a suitable catalyst, which enables simultaneous soot filtration 
and combustion [2]. With this system, the filter could be regenerated at a temperature comparable to that of diesel exhaust gases. Soot oxidation catalysts have been applied in three different ways: (i) as precursor compounds, soluble in the diesel fuel; (ii) as catalytic compounds that are injected upstream of the soot-loaded filter; and (iii) as a catalytic coating on the filter itself. Because of the logistic and possible environmental problems related to the first two options, the last option is the most desirable way to apply a catalyst for soot oxidation [7].

Another matter of concern is the presence of nitric oxide in diesel exhausts (typically around 1000-2000 ppm). This toxic compound should be eliminated in order to accomplish the increasingly severe limits imposed by law. NOx adsorbers (traps), combined with a reduction catalyst, constitute a relatively new control technology, which has been developed for partial lean burn gasoline engines and for diesel engines [8]. The adsorbers, which are incorporated into the catalyst washcoat, chemically bind nitrogen oxides during lean engine operation. After the adsorber capacity is saturated, the system is regenerated and released $\mathrm{NO}_{\mathrm{x}}$ is catalytically reduced during a period of rich engine operation [9]. In the case of diesel engines, since a rich operation is not feasible, periodic fuel injections are necessary.

On the other hand, nitric oxide favors the efficiency of the catalytic combustion of soot, because $\mathrm{NO}_{2}$ is an oxidant stronger than $\mathrm{O}_{2}$, enabling the regeneration of the filter at lower temperatures. This is the principle of CRT filter (Continuously Regenerating Technology). This system was developed and commercialized by Johnson Matthey, Catalysts division. It is claimed that the third generation CRT filter is able to reduce $\mathrm{HC}$ and PM by over $90 \%$ and CO by over $70 \%$, but is not efficient to reduce $\mathrm{NO}_{x}$ emissions.

The CRT particulate filter utilizes Johnson Matthey's patented process which, as said above, oxidizes soot with $\mathrm{NO}_{2}$ at a lower temperature than with oxygen [10]. This lower temperature is compatible with typical diesel exhaust temperatures, so no supplemental heat is required. The device is made up of two chambers. The first contains a substrate coated with a proprietary, highly-active platinum oxidation catalyst designed to oxidize a portion of the $\mathrm{NO}$ in the exhaust to $\mathrm{NO}_{2}$. $\mathrm{NO}_{2}$ generation is the key to the oxidation of soot collected by the wall flow filter and the heart of the Johnson Matthey's patent. The same catalyst also converts $\mathrm{CO}$ and $\mathrm{HC}$ into $\mathrm{CO}_{2}$ and $\mathrm{H}_{2} \mathrm{O}$. In the second chamber, exhaust flows through a wall-flow filter, where gaseous components pass through, but the soot is trapped on the walls of the filter. The trapped soot is then removed by the $\mathrm{NO}_{2}$ produced by the catalyst in the first chamber [11].

The complexity of the systems that are commercially available nowadays, motivate increasing efforts devoted to obtain more simple processes. In this vein, soot oxidation in catalytic traps has been recently proposed as an alternative to simultaneously eliminate both NOx and particle contaminants [12]. In our group, it has been demonstrated that the reaction between soot particles and $\mathrm{NO} x$ molecules originated by the decomposition of the trapped nitrate species is feasible when a catalytic trap composed of a mixed oxide of $\mathrm{Ba}, \mathrm{Co}, \mathrm{K}$ and $\mathrm{Ce}$ is used [13]. The reaction between nitrate species and soot is also the basis of the diesel particulate and $\mathrm{NO}_{x}$ reduction process (DPNR Toyota system). Nitrates are formed in a 


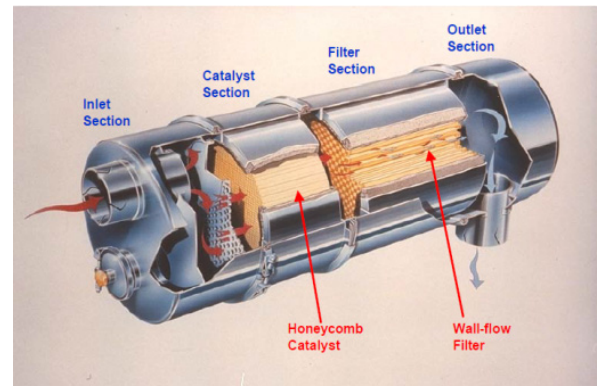

Figure 2. CRT particulate filter utilizes Johnson Matthey's.

catalytic trap composed of an alkali metal oxide after the $\mathrm{NO}$ to $\mathrm{NO}_{\mathrm{x}}$ reaction takes place over the Pt atoms. It is believed that surface nitrates are decomposed producing $\mathrm{NO}$ and very reactive $\mathrm{O}$ atoms, which are responsible for soot oxidation $[14,15]$. The fate of NO molecules is to form nitrates again. Once it is saturated, the alkali-metal trap should be regenerated by running the engine in rich conditions or by adding fuel into the exhaust stream. However, in another work [16] it is reported that the presence of soot particles prevents $\mathrm{NO}_{\mathrm{x}}$ traps from employing their full trapping capacity, which could result in a lack of efficiency of the DPNR Toyota technology.

\section{Structured catalysts}

A large number of catalyst formulations have been reported for soot combustion, and the soot-to-catalyst contact appears to be one of the most important problems to overcome. Some reviews have recently offered updates on new technologies for diesel emission control. Despite the abundant studies on both soot combustion and $\mathrm{NO}_{\mathrm{x}}$ abatement carried out with powder formulations, only a handful of papers have been published using structured catalysts, which constitutes a more realistic approach. In particular, for soot particles abatement, an adequate morphology of the catalyst is required so as to improve the contact between catalyst and soot. For practical purposes, the catalytically active component should be supported as a film on a structured substrate, thus allowing simultaneous soot filtration and combustion.

Even though powder catalysts are unable to be used under real conditions in the exhaust pipes, the powder form is very useful to study the catalytic performance and the effect of different operating variables on their activities such as the soot-catalyst contact type [17-19], which is a very important factor in this type of reaction. Other factors of interest are the soot to catalyst ratio and the concentration of $\mathrm{NO}_{x}$ and $\mathrm{O}_{2}$, because the concentration of these gases can change during the diesel engine operation [20].

A large number of powder catalysts have been investigated for controlling the diesel engines exhaust emission, the main objective of most of these studies being to improve the catalytic performance for soot combustion. There are numerous articles reporting the use of precious metals supported on $\mathrm{Al}_{2} \mathrm{O}_{3}, \mathrm{Ce}-\mathrm{Zr}$ mixed oxide [21], $\mathrm{CeO}_{2}$ and $\mathrm{TiO}_{2}$ [18] for this 
application, although the cost of these metals is really high. For this reason, other bulk catalysts have been extensively studied in the last decade such as hydrotalcite-like compounds ( $\mathrm{CuMgAl}$ [22] and $\mathrm{Mn}_{x} \mathrm{Mg}_{3}-\mathrm{AlO}$ [23]), spinels $\left(\mathrm{ZnAl}_{2} \mathrm{O}_{4}\right.$ [24] and $\mathrm{CoAl}_{2} \mathrm{O}_{4}$ [25]), perovskites ( $\mathrm{LaMnO}_{3}$ [26], $\mathrm{La}_{1-x} \mathrm{~K}_{x} \mathrm{Co}_{1-y} \mathrm{Ni}_{\mathrm{y}} \mathrm{O}_{3-\delta}$ [27], $\mathrm{La}_{0.9} \mathrm{~K}_{0.1} \mathrm{Co}_{1-x} \mathrm{FexO}_{3-\delta}$ [28] and $\mathrm{BaCoO}_{3-\mathrm{y}}$ [29]), mixed oxides (La-Ce oxide, Nd-Ce oxide, Fe-Ce oxide, $\mathrm{Cu}-\mathrm{Ce}$ oxide [30]) and single oxides ( $\mathrm{SrO}, \mathrm{CeO}_{2}, \mathrm{Co}_{3} \mathrm{O}_{4}, \mathrm{La}_{2} \mathrm{O}_{3}$ [31]). Besides, catalytic formulations containing oxide components supported on different oxides have resulted good catalysts for the control of diesel engines exhaust emissions. For example, $\mathrm{Co}_{3} \mathrm{O}_{4}, \mathrm{KNO}_{3}$ and $\mathrm{BaCO}_{3}$ supported on $\mathrm{ZrO}_{2}$ $\left(\mathrm{Co}, \mathrm{Ba}, \mathrm{K} / \mathrm{ZrO}_{2}\right)$ or $\mathrm{CeO}_{2}\left(\mathrm{Co}, \mathrm{Ba}, \mathrm{K} / \mathrm{CeO}_{2}\right)$, where there occurs a combination of the moderated activities of $\mathrm{ZrO}_{2}$ or $\mathrm{CeO}_{2}$ with the high activity of dispersed $\mathrm{Co}_{3} \mathrm{O}_{4}$ for the soot combustion, along with the fact that $\mathrm{KNO}_{3}$ favors the soot oxidation by improving the contact between the soot and the catalytic surface [13,32].

The main function of the catalysts mentioned above is that of being active for the catalytic combustion of soot, but other catalysts that have been developed for the abatement of $\mathrm{NO}_{x}$ emissions (catalytic traps) can also be employed for soot combustion. One of the most widely used compounds for the absorption of $\mathrm{NO}_{\mathrm{x}}$ is barium, which traps this gaseous contaminant through the formation of the corresponding nitrate. At high temperatures, nitrate decomposes releasing $\mathrm{NO}_{2}$, which in turn reacts with soot.

To reduce the NOx concentration, the selective catalytic reduction (SCR) is the most commonly employed method, and $\mathrm{NH}_{3}$ is the most common reducing agent. Commercially, $\mathrm{NH}_{3}$ is generated in situ by urea decomposition and the BlueTec system developed by Mercedes Benz uses a 32.5\% urea solution for $\mathrm{NH}_{3}$ generation. The best SCR catalysts are zeolites exchanged with different metals as $\mathrm{Fe}$ or $\mathrm{Cu}[33,34]$, although oxides as $\mathrm{CeO}_{2}-\mathrm{TiO}_{2}$ or Ce-W-Ti mixed oxides have also been tested [35,36].

In the reaction of $\mathrm{NH}_{3}$ with $\mathrm{NO}, \mathrm{O}_{2}$ is required to form $\mathrm{H}_{2} \mathrm{O}$ so as to consume the excess hydrogen from $\mathrm{NH}_{3}$. The reaction of $\mathrm{NH}_{3}$ with $\mathrm{NO}_{2}$ is a much slower reaction. However, equal amounts of $\mathrm{NO}$ and $\mathrm{NO}_{2}$ undergo selective reduction with $\mathrm{NH}_{3}$ in a reaction that is an order of magnitude faster than the reaction of $\mathrm{NH}_{3}$ with either $\mathrm{NO}$ or $\mathrm{NO}_{2}$ alone. This has been called "fast SCR" reaction, and $\mathrm{O}_{2}$ does not take part in the reaction. As it can be noticed, $\mathrm{NO}_{2}$ has the role of reacting with the hydrogen that $\mathrm{O}_{2}$ consumes in the reaction of $\mathrm{NO}$ with $\mathrm{NH}_{3}$. Since this mixed reaction is indeed "fast", it is important to adjust the $\mathrm{NO} / \mathrm{NO}_{2}$ ratio by the appropriate oxidation of $\mathrm{NO}$ to $\mathrm{NO}_{2}$ before the SCR catalyst on a vehicle, and this is done by carefully selecting the catalyst [1].

The powder catalyst itself cannot be used for a practical application in the diesel engine exhaust pipe and as stated above, a catalytic coating on the filter appears to be the best option to use a catalyst for soot oxidation Therefore, a substrate containing the catalytic coating must be used as a system that can withstand the severe operating conditions of the exhaust pipe, high flows, high corrosive atmospheres, thermal shocks and vibrations. These substrates must have filtration properties, because one of the pollutants is solid (soot particles). The filter walls can be coated with a catalytic layer, in which the retained soot particles are burnt and the $\mathrm{NO}_{x}$ trapped at the temperature of the exhaust gases. 
The most extensively used substrates for this purpose are ceramic monoliths [37] (Figure 3a), which consist of square parallel channels along the axial direction with thin porous walls. To act as a filter, the channels are open at one end, but plugged at the other one. Therefore, the exhaust gas soot particles are forced to flow through the filter walls, which are coated with a catalytic layer.

Other substrates used as filters are foams [38] (Figure 3b), which can be made of either ceramic or metallic materials. The rigid open-cell foam type allows exhaust gases to flow through and traps soot particles on its complex structure. The filter obstructions by soot particles is difficult since these soot particles are catalytically burnt through the catalytic layer coated onto the foam surface, i.e., foams provoke low pressure drops.

Although monoliths and foams are the most widely studied substrates for the preparation of structured catalysts, other merging substrates that can be considered for controlling the diesel engines exhaust pollutants are ceramic papers [39] (Figure 3c) and wire meshes [40] (Figure 3d). For the former, the catalytic components can be either coated onto the ceramic fiber or held as particles between the ceramic fibers [20] and for the latter, similar to foams, the filaments of the wire mesh can be coated with the catalyst and act as a catalytic filter [41].
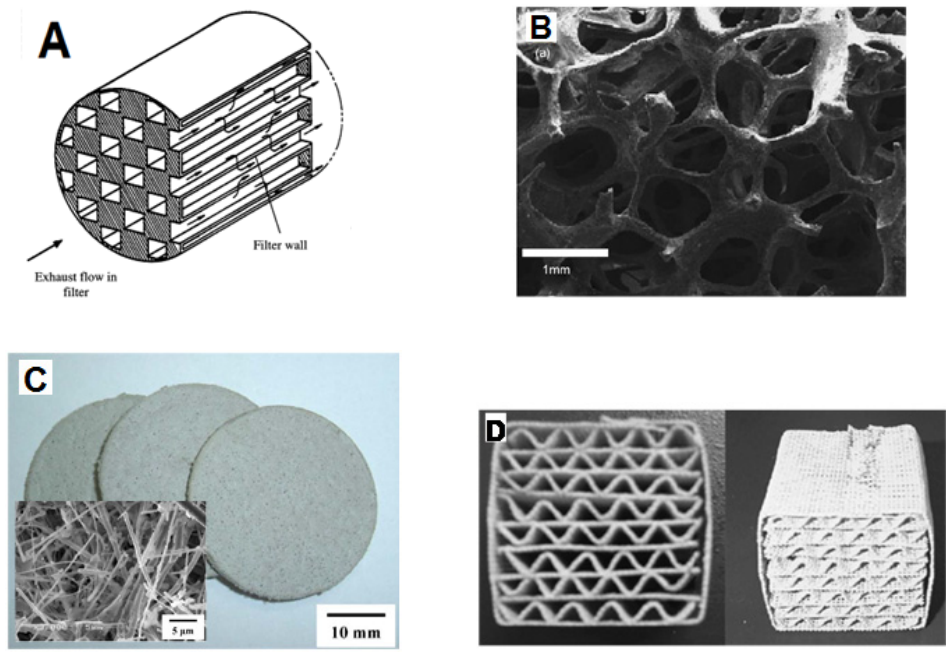

Figure 3. Four types of structures can be used to make a catalytic diesel particulate filter: A. Monolith, B. Ceramic Foam, C. Ceramic Paper and D. Wire Mesh.

Meille [39] described different coating methods: washcoating using a suspension $\left(\mathrm{La}_{2} \mathrm{O}_{3}-\right.$ $\left.\mathrm{Al}_{2} \mathrm{O}_{3}, \mathrm{Pd} / \mathrm{ZnO}, \mathrm{CuO} / \mathrm{ZnO}-\mathrm{Al}_{2} \mathrm{O}_{3}\right)$, sol-gel deposition $\left(\mathrm{Pt} / \mathrm{Al}_{2} \mathrm{O}_{3}, \mathrm{Rh} / \mathrm{Al}_{2} \mathrm{O}_{3}, \mathrm{Pd} / \mathrm{Al}_{2} \mathrm{O}_{3}\right.$, $\left.\mathrm{Pd} / \mathrm{La}_{2} \mathrm{O}_{3}, \mathrm{Pd} / \mathrm{SiO}_{2}\right)$, hybrid method between suspension and sol-gel $\left(\mathrm{CeO}_{2}-\mathrm{ZrO}_{2}-\mathrm{La}_{2} \mathrm{O}_{3}-\right.$ $\left.\mathrm{Al}_{2} \mathrm{O}_{3}, \mathrm{CuO} / \mathrm{ZnO}-\mathrm{Al}_{2} \mathrm{O}_{3}\right)$, electrophoretic deposition $\left(\mathrm{Al}_{2} \mathrm{O}_{3}\right)$, electrochemical deposition $(\mathrm{Cu}-$ $\mathrm{Zn})$, electroless plating $(\mathrm{Cu}-\mathrm{Zn})$ and impregnation $\left(\mathrm{Rh}, \mathrm{Ni} / \mathrm{La}_{2} \mathrm{O}_{3}, \mathrm{Fe}_{2} \mathrm{O}_{3}\right)$. Other methods described are chemical vapor deposition $\left(\mathrm{Al}_{2} \mathrm{O}_{3}, \mathrm{Mo}_{2} \mathrm{O}_{3}\right)$, physical vapor deposition $(\mathrm{Cu}, \mathrm{Pt}$, 
Mo, $\mathrm{Zr}$, $\left.\mathrm{La}_{2} \mathrm{O}_{3}, \mathrm{Al}_{2} \mathrm{O}_{3}\right)$, flame assisted vapor deposition $\left(\mathrm{NiO}-\mathrm{Al}_{2} \mathrm{O}_{3}\right)$ and flame spray deposition $\left(\mathrm{Au} / \mathrm{TiO}_{2}\right)$.

This chapter mainly focuses on different types of structured catalysts developed in our group for the control of diesel pollutants. Cobalt, barium and potassium deposited either on $\mathrm{ZrO}_{2}$ or $\mathrm{CeO}_{2}$ powders resulted efficient for the combustion of soot. These elements have been used to coat different foams and monolithic structures [42-43]. In order to evaluate the performance of these systems, soot particles were impregnated onto the structured catalysts using slurry of soot in n-hexane, thus giving place to loose contact. Despite the nonhomogeneous nature of the foam, the application of the said method yielded satisfactory results regarding the reproducibility towards the catalytic behavior, comparable to that obtained with the powder catalyst.

\subsection{Monoliths}

The monolith catalysts were first developed in the 1970s for automotive exhaust gas treatment mainly to control hydrocarbon and $\mathrm{CO}$ emissions. After that, significant improvements were introduced until obtaining the three way gasoline catalyst converter (TWC). Operating under stoichiometric air to fuel ratio, this TWC simultaneously converts $\mathrm{CO}, \mathrm{HC}$ and $\mathrm{NO}_{x}$ into $\mathrm{CO}_{2}, \mathrm{H}_{2} \mathrm{O}$ and $\mathrm{N}_{2}$. During the last three decades, monolith reactors have been widely used as air pollution control systems due to their relevant characteristics: low pressure drop, high specific external surface area and less catalyst attrition compared to those of the packed-bed reactors. Standing out among these applications, the one used by certain commercial airlines in order to ensure a clean and safe environment in the airplane cabin, namely the metal monolith system, can be mentioned. The light weight of a metal monolith coupled with a low pressure drop makes this a cost-effective technology. In some industrial processes, nitrogen oxides ( $\mathrm{NO}_{\mathrm{x}}$ ) are produced and the structured catalysts made with monoliths are used for the selective reduction of $\mathrm{NO}_{x}$, with $\mathrm{NH}_{3}$. Besides, a large amount of volatile organic compounds (VOCs) is produced in several industries. In these cases, the monolith catalyst is used to remove the VOCs. After many years of research and development, the catalytic combustor has now been commercialized for gas turbines replacing traditional burners. It uses large air excess, generates sufficient temperatures to operate the turbine, but with virtually no emission of $\mathrm{CO}, \mathrm{HC}$ or $\mathrm{NO}$. Other applications are the hydrogen generation for the fuel cell by steam reforming of hydrocarbons, water gas shift and preferential oxidation of CO [44].

Concerning diesel exhaust particulate removal, wall-flow diesel particulate filters (DPFs) are considered the most effective devices for the control of diesel particulate emissions. A requirement for the reliable operation of the DPFs, however, is the periodic and/or continuous regeneration of the filters.

This type of substrate was developed for the catalytic after-treatment of gasoline engine exhausts. Some modifications were made to the traditional monolith to be used as diesel particulate filter. The monoliths most widely used are made of cordierite (ceramic material consisting of magnesia, silica, and alumina in the ratio of 2:5:2) or silicon carbide, materials 
that can withstand high temperatures, as those achieved during the regeneration of the diesel particulate filter. Besides, these substrates are also made of aluminum titanate, alumina or mullite. Metallic monoliths, extensively used as structured supports of catalysts in other reactions, are not porous and therefore not used as diesel particulate filters.

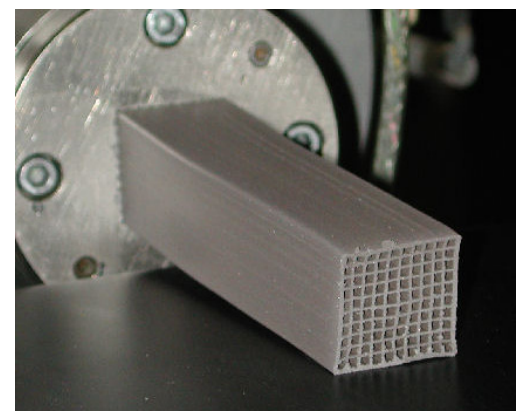

Figure 4. Fabrication of a ceramic monolith by extrusion.

The ceramic monolith structures are produced via extrusion [45], as shown in Figure 4. The monolith cells can have different geometries; the most popular is the square one, although there are monoliths with hexagonal and triangular cells (Figure 5). The characteristic parameters that describe the monolith structure are presented in Table 1 [46]. The cell density is defined as the number of cells per unit area, where the area is generally described in square inches and the most common monoliths have 100, 200 or $400 \mathrm{cpsi}$ (cells per square inch). Since the catalytic filters have the double function of filtering particles and burning them, the structural properties (porosity, surface area, wall thickness) have a central role in their efficiency. The wall thickness is an important parameter since it is related to the filter capacity and pressure drop caused by the monolith. Although high porosities are desirable for wall flow-through type filters, this make structures more fragile and implies low rupture modulus values.

As said above, there are different methods to generate a catalytic layer onto the substrate walls. In general, the combination of the active components for the layer is chosen from those active catalysts previously evaluated as powders. In what follows, a summary is included of some methods employed for the synthesis of structured catalysts using a monolith as structured substrate:

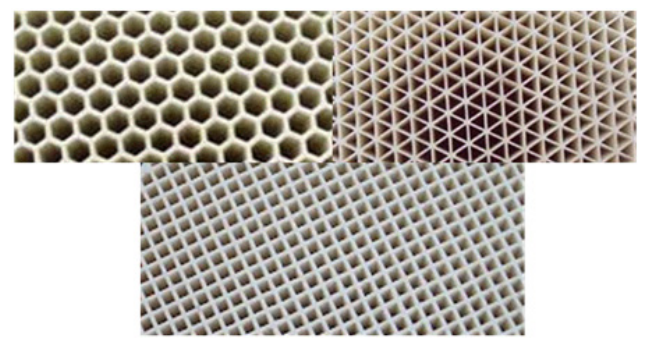

Figure 5. Different forms of cells in a monolith. 


\begin{tabular}{|c|c|c|c|}
\hline \multirow[b]{2}{*}{ Characteristics } & \multicolumn{3}{|c|}{ Commercial denomination } \\
\hline & $100 / 17$ & $200 / 12$ & $400 / 4.5$ \\
\hline $\begin{array}{l}\text { Cell Density } \\
\text { (cpsi) }\end{array}$ & $\begin{array}{l}100 \\
155\end{array}$ & $\begin{array}{l}200 \\
310\end{array}$ & 400 \\
\hline $\begin{array}{l}\text { Wall Thickness } \\
\text { (in) } \\
(\mathrm{mm}) \\
\end{array}$ & $\begin{array}{l}0.017 \\
0.432\end{array}$ & $\begin{array}{l}0.012 \\
0.302 \\
\end{array}$ & $\begin{array}{c}0.0045 \\
0.102 \\
\end{array}$ \\
\hline $\begin{array}{l}\text { Open Frontal Area (OFA) } \\
(\%)\end{array}$ & 34.5 & 34.5 & 84 \\
\hline $\begin{array}{l}\text { Geometric Surface Area (GSA) } \\
\left(\mathrm{in}^{2} / \mathrm{in}^{3}\right) \\
\left(\mathrm{m}^{2} / \mathrm{l}\right)\end{array}$ & $\begin{array}{l}33.3 \\
1.31 \\
\end{array}$ & $\begin{array}{l}47.0 \\
1.85 \\
\end{array}$ & $\begin{array}{c}69 \\
2.72 \\
\end{array}$ \\
\hline $\begin{array}{l}\text { Hydraulic Diameter } \\
\text { (in) } \\
(\mathrm{mm})\end{array}$ & $\begin{array}{c}0.0813 \\
2.11 \\
\end{array}$ & $\begin{array}{c}0.059 \\
1.49 \\
\end{array}$ & $\begin{array}{c}0.0455 \\
1.09 \\
\end{array}$ \\
\hline $\begin{array}{l}\text { Modulus of Rupture } \\
\text { (psi/cpscm) }\end{array}$ & 350 & 300 & \\
\hline $\begin{array}{l}\text { Porosity } \\
(\%)\end{array}$ & 48 & 48 & 48 \\
\hline $\begin{array}{l}\text { Coefficient of Thermal Expansion } \\
\left(\times 10^{-7} \mathrm{~cm} / \mathrm{cm} /{ }^{\circ} \mathrm{C}\left(25-800^{\circ} \mathrm{C}\right)\right) \\
\text { Maximun average }\end{array}$ & 5 & 5 & 5 \\
\hline $\begin{array}{l}\text { Mean Pore Size } \\
\text { (micron) }\end{array}$ & 13 & 13 & 13 \\
\hline
\end{tabular}

Table 1. Characteristics of three commercialized ceramic monoliths

Solution combustion synthesis: This method consists in the dipping of the ceramic support in the aqueous solution of its precursors, which is then placed into an oven at a high temperature. The aqueous phase is rapidly brought to boil, the precursors mixture ignite and the synthesis take place in situ. This method has been applied to deposit catalysts as perovskites or spinels, as $\mathrm{La}_{0.9} \mathrm{~K}_{0.1} \mathrm{Cr}_{0.9} \mathrm{O}_{3}[47,48], \mathrm{LiCoO}_{2}[49,50]$ and $\mathrm{LaCr}_{0.9} \mathrm{O}_{3}$ [51] over ceramic monoliths.

Impregnation: The catalysts are directly deposited on the monolith by immersing the structured substrate into a solution of the precursors of the catalyst; then the monolith is blown to eliminate the excess of solution, and finally it is dried and calcined. This method was used to deposit $\mathrm{Cu} / \mathrm{K} / \mathrm{Mo}$ over the monolith [7,52]. Also, coatings of $\mathrm{KNO}_{3} / \mathrm{CeO}_{2}$, $\mathrm{K}_{2} \mathrm{CO}_{3} / \mathrm{CeO}_{2}$ or $\mathrm{KOH} / \mathrm{CeO}_{2}$ were performed over monoliths. In a first step, Ce was deposited using a solution of $\mathrm{Ce}\left(\mathrm{NO}_{3}\right)_{3}$ and once $\mathrm{CeO}_{2}$ was formed after calcination, potassium precursors were deposited [53]. 
Washcoating: This method consists in immersing the monolith into a suspension of either catalyst particles or catalytic precursors; in the former case, the catalyst is synthesized as powder and then, the suspension is prepared. With this method $\mathrm{Co}, \mathrm{K} / \mathrm{Al}_{2} \mathrm{O}_{3}$ or $\mathrm{Cu}, \mathrm{K} / \mathrm{Al}_{2} \mathrm{O}_{3}$ [54] and $\mathrm{Cu}-\mathrm{K} / \mathrm{Al}_{2} \mathrm{O}_{3}, \mathrm{Co}-\mathrm{K} / \mathrm{Al}_{2} \mathrm{O}_{3}$ or $\mathrm{V}-\mathrm{K} / \mathrm{Al}_{2} \mathrm{O}_{3}$ [54] were deposited over monolithic structures.

Combination methods: In some cases, the combination of more than one technique is used. For example, Banús et al. deposited the catalyst $\mathrm{Co}, \mathrm{Ba}, \mathrm{K} / \mathrm{ZrO}_{2}$ over monoliths in two steps. First, a layer of $\mathrm{ZrO}_{2}$ was deposited on the monolith walls by the washcoating method, using a $\mathrm{ZrO}_{2}$ colloidal suspension and then, after calcination, the active metals $(\mathrm{Co}, \mathrm{Ba}$ and $\mathrm{K}$ ) were impregnated [42].

\subsection{Foams}

Among the various diesel particulate filters (DPFs), ceramic foams are attractive structured systems that can be prepared from a range of materials and have characteristics that make them desirable as substrates for structured heterogeneous catalysts. They exhibit high porosities with a significant degree of interconnectivity among spherical-like cells through openings or windows, which results in low pressure drop. While the more conventional wall-flow type monoliths act as "cake filters", foams act as deep bed filters. In monoliths, the surface filtration ("cake formation") gives good particulate collection efficiency, but a significant pressure drop occurs as the layer of soot particulates deposited on the filter walls grows. In the case of the deep filtration type filters (foams), a good penetration/dispersion of particulate inside the trap matrix is obtained, thus allowing constant collection efficiency. Although the retention efficiency is often low, this can be overcome with an appropriate trap design. The use of different types of foams has been the object of several interesting research studies aimed at eliminating diesel contaminants produced by diesel vehicles. Other catalytic applications, such as $\mathrm{CO}_{2}$ reforming, have been explored. A low surface area ceramic substrate gives desirable physical and mechanical properties but the choice of an adequate washcoat provides a high surface area so that catalytic films could enhance their activities when depositing them on the washcoat-structured substrate.

There are two types of foams, those with open pores [56] (Figure 6a) and those with closed pores [57] (Figure 5b). Nevertheless, only the former type can be used for making structured catalysts since the latter, containing closed pores, make it impossible for any gas to flow through and is only used as isolating material. Foams are mainly defined by the pore number per linear inch (pores per inch, ppi). In Figure 7, open pore metallic foams with different ppi are shown [58]; the higher the ppi number, the smaller the pore dimensions. Smaller pore size increases the pressure drop, as observed in Figure 8 [59]. The filter efficiency of foams is related to a high ppi number and to the filter length. On the other hand, a diesel particulate filter with a high ppi number provokes a high pressure drop, which could deteriorate the performance of diesel engines. 


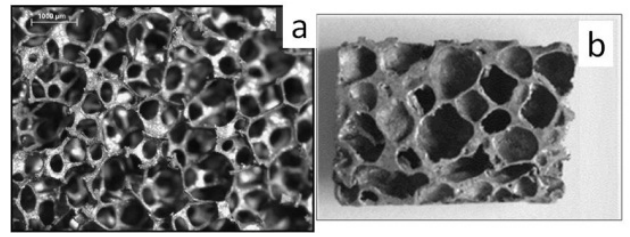

Figure 6. Type of foam. Open pores (a) and closed pores (b).

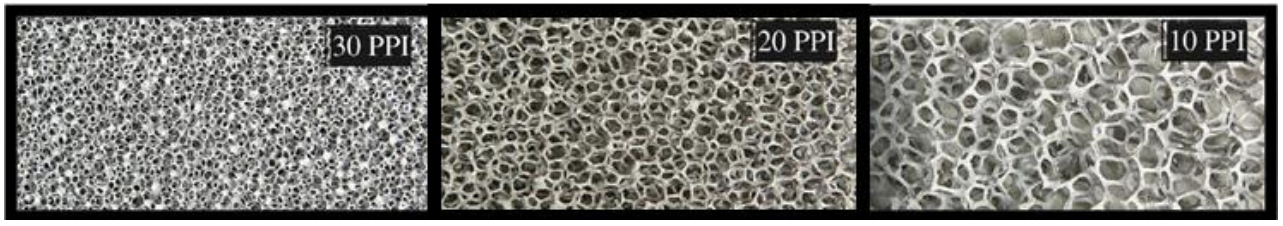

Figure 7. Metallic foam of different pores per inch.

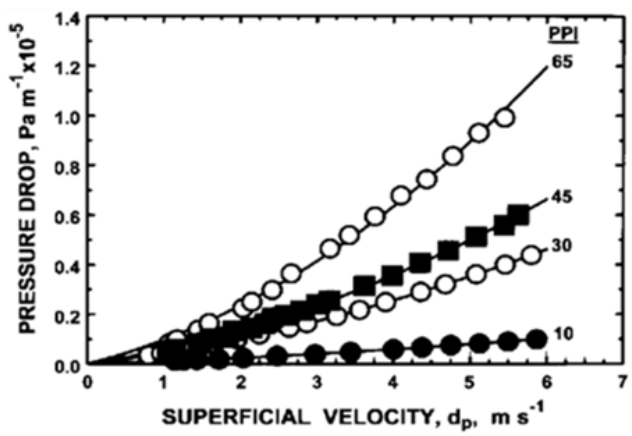

Figure 8. Pressure drop as a function of pores per inch (ppi).

Ceramic or metallic foams of open pores can also be used as substrate for a catalytic coating in numerous reactions or catalytic processes such as methane catalytic oxidation, hydrogen production, engine gas exhaust purification, ammonia oxidation to obtain nitric acid, methanol partial oxidation, hydrocarbon total oxidation, $\mathrm{CO}_{2}$ reforming, and FischerTropsch synthesis, among others.

Metallic foams are made of either a single metal such as aluminum, nickel, or copper, or of alloys such as brass, $\mathrm{Ni}-\mathrm{Fe}, \mathrm{Ni}-\mathrm{Cr}$ or $\mathrm{Ni}-\mathrm{Cr}-\mathrm{Al}, \mathrm{Fe}-\mathrm{Cr}-\mathrm{Al}$ or stainless steels, whereas ceramic foams are made of $\mathrm{Al}_{2} \mathrm{O}_{3}, \mathrm{Mg}_{2} \mathrm{Al}_{4} \mathrm{Si}_{5} \mathrm{O}_{18}, \mathrm{SiC}, \mathrm{Al}_{2} \mathrm{O}_{3}-\mathrm{ZrO}_{2}, \mathrm{Y}_{2} \mathrm{O}_{3}-\mathrm{Al}_{2} \mathrm{O}_{3}, \mathrm{Al}_{2} \mathrm{O}_{3}-\mathrm{SiO}_{2}$ and $\mathrm{TiO}_{2}$. By far, the most studied ceramic foams are the $\mathrm{Al}_{2} \mathrm{O}_{3}$ ones [60].

Different techniques are used for the manufacturing of ceramic foams:

- Replication of artificial or natural foams [61,62],

- Employing generator agents of pores, as vegetal flours or polymers [63,64] and

- Foaming methods, where either by agitation [65] or by the fast evaporation of the solvent, pores are formed [66]. 
On the other hand, metallic foams are produced in different ways such as [67]:

- Bubbling gas through a molten metal.

- Stirring a foaming agent (typically $\mathrm{TiH}_{2}$ ) into a molten alloy (typically an aluminum alloy) and controlling the pressure while cooling.

- Consolidating a metallic powder (the most commonly used ones are aluminum alloys) with a particulate foaming agent $\left(\mathrm{TiH}_{2}\right)$ followed by heating into the mushy state. When the foaming agent generates hydrogen, the material is expanded and the foam is formed.

- Manufacturing ceramic mold from a wax or polymer-foam precursor, followed by burning-out of the precursor and pressure infiltration with molten metal or metal powder slurry which is then sintered.

- Vapor phase deposition or electrodeposition of a metal onto a polymeric foam precursor, which is burned out, leaving cell edges with hollow cores.

- Dissolution of a gas (typically hydrogen) in a liquid metal under pressure, allowing it to be released in a controlled way during subsequent solidification.

Concerning particulate filters, as stated, the most commonly used foams are ceramic ones, made of $\alpha-\mathrm{Al}_{2} \mathrm{O}_{3}$ and 65 or 50 ppi. According to the process used to produce the foam, the final product is between 1 or 2 inch thickness, so that for the fabrication of the diesel particulate filter, several foam discs are placed in a container [68], as shown in Figure 9. Besides the typical material used for diesel particulate foam filters $\left(\alpha-\mathrm{Al}_{2} \mathrm{O}_{3}\right)$, other materials are $\mathrm{SiC}$, zirconia toughened alumina (ZTA) and zirconia toughened mullite (ZTM). These materials are selected due to their resistance to corrosion in atmospheres and high temperatures, which are operating conditions of diesel exhaust filters. Metallic foams without any pre-treatment are not suitable to be used as filters because of the low resistance under severe operating conditions. However, after either passivation or coating with the appropriate compounds, these metallic foams can be used as diesel particulate filter. Only a few articles concerning metallic foams as filters are available in the literature and they mainly report the use of foams made of stainless steels, FeCrAl alloys and nickel.

Ciambelli and coworkers have coated the ceramic foam walls with $\mathrm{Cu} / \mathrm{V} / \mathrm{K} / \mathrm{Cl}$, through several cycles of immersion into an aqueous solution of the catalyst precursor salts, drying at $120^{\circ} \mathrm{C}$ and calcining at $700^{\circ} \mathrm{C}$ overnight [68-72]. Through this process, different ceramic foams have been coated with vanadates [73-77] or with $\mathrm{Pb}-\mathrm{Co}$ [78]. Another method for obtaining the catalytic coating is by dipping the ceramic foam into a molten solution containing precursor salts and then, eliminating the solution excess by blowing [79-81] and finally, calcining the coated monoliths.

Banús et al. reported that $\mathrm{Co}, \mathrm{Ba}, \mathrm{K} / \mathrm{ZrO}_{2}$ is a good powder catalyst for both soot combustion and $\mathrm{NO}_{x}$ trapping [32] and they produced $\mathrm{Co}, \mathrm{Ba}, \mathrm{K} / \mathrm{ZrO}_{2}$ coatings onto calcined metallic foams [43] and ceramic foams [61]. The first step for obtaining this catalytic coating was to deposit a $\mathrm{ZrO}_{2}$ layer by immersing the foam into a commercial suspension of $\mathrm{ZrO}_{2}$ nanoparticles $\left(\mathrm{ZrO}_{2} /\right.$ foam). Then, the impregnation of the active metals $(\mathrm{Co}, \mathrm{Ba}, \mathrm{K})$ to the zirconia layer was done by dipping the $\mathrm{ZrO}_{2} /$ foam into a solution of the metal salts. The 


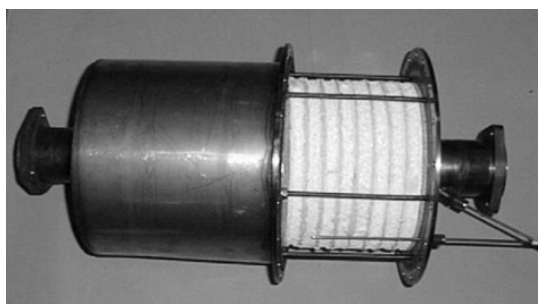

Figure 9. Image of radial flow foam trap.

$\mathrm{ZrO}_{2}$ layer increases the surface area and in the case of the metallic foam, it also protects its surface walls from the corrosion and the high temperature. It has been reported that $\mathrm{CeO}_{2}$ also has the same effect over FeCrAl alloy fibers [82]. In the other case, pure nickel foam is coated with a powder FeNiCrAl alloy, and after the rapid transient liquid phase sintering, a homogeneous alloy foam is formed [83].

\subsection{Wire-meshes}

It has been reported that by covering a wire mesh with a porous ceramic layer through a modified thermal spray technique an active and durable catalyst can be produced [37]. The surface area of the porous ceramic layer can be increased by an in-situ precipitation technique, through washcoating or by means of sol-treatments. The ceramic layer is finally covered with a catalytically active material, e.g., Pd, Pt or metal oxides. Wire-mesh catalysts combine the excellent mass and heat transfer performance of a pellet-type catalyst with the low pressure drop of a monolith. The effects of pore diffusion during combustion are relatively small due to the shell like design of the catalyst layer. Thus, the catalyst efficiency is considerably improved compared with pellet or monolith catalysts. The effects of catalyst clogging and fouling can be handled as these structured catalysts are easy to disassemble and to clean. Wire-mesh catalysts also offer a great flexibility with respect to dimensions that make retrofit installations easier.

A study of soot combustion on wire meshes formed inside a cylindrical filter is being carried out in a joint collaborative work between our group and a team from the University of the Bask Country. Preliminary results using an active phase composed by $\mathrm{Co}, \mathrm{Ba}, \mathrm{K} / \mathrm{CeO}_{2}$ coated on stainless steel wire meshes are promising.

\subsection{Ceramic papers}

A material that has been extensively used as particle filter is cellulose paper, which can be flexibly adapted to different conformations. Besides, the paper-like structure, with interconnected pore spaces formed by the fiber network, may provide an adequate matrix that promotes desirable exhaust gas diffusion within the catalyst layer where filtration of particulate matter along with the combustion of trapped soot would take place. However, in the case of diesel soot oxidation, the filter should resist the high temperatures of the exhaust, a requirement that cannot be met by cellulose fibers. It has been recently shown that the use 
of ceramic fibers along with cellulose ones and the application of papermaking techniques result in high-temperature resistant ceramic papers. The addition of cellulosic fibers in low proportion favors the fiber mat consolidation, not only when the mat is wet but also when the mat is dried. And finally, a calcination step is needed, by which cellulose fibers are burnt and a matrix composed of ceramic fibers is obtained. In this way, a stable porous structure suitable for gas flow-through applications can be obtained.

Different types of ceramic fibers can be used thus allowing the preparation of a variety of structured matrices. However, fiber length constitutes a limitation and ceramic fibers of at least $600 \mu \mathrm{m}$ of length are needed. Most generally used ceramic fibers are a mixture of $\mathrm{SiO}_{2}$ $(50 \%)$ and $\mathrm{Al}_{2} \mathrm{O}_{3}(48 \%)$ and they are frequently denoted only as ceramic fibers, although some papers report the use of fiber rods of mullite $\left(3 \mathrm{Al}_{2} \mathrm{O}_{3} .2 \mathrm{SiO}_{2}\right)$ [84] or glass fiber [85].

Likewise, the addition of a binder is necessary to obtain optimum mechanical properties that allow an easy manipulation of ceramic papers after calcination, i.e., after cellulose fibers are burnt. The kind and amount of ceramic binder should be selected in order to obtain a strong but flexible structure. In general, most published papers employ alumina sol as a binder for enhancing the physical strength of the catalyst paper [38, 84, 86-89], although some papers use $\mathrm{TiO}_{2}$ sol $[90,91]$ or $\mathrm{SiO}_{2}$ sol [92]. Our group is currently studying the use of borate compounds as binder to enhance the mechanical properties of ceramic papers. It has been found that ceramic papers with different properties can be obtained by modifying the final calcination temperature. Although none of the borate tested melt after calcination up to $750^{\circ} \mathrm{C}$, individual particles began to sinter as the calcination temperature increased thus joining ceramic fibers and giving ceramic papers better mechanical properties (unpublished results).

Either during or after the synthesis of the ceramic paper, a catalyst can be added; thus, a ceramic paper with catalytic properties is obtained. In the last few years, the idea behind the so called "catalytic paper" has been to apply this paper for making structured catalysts for different reactions, for example methanol steam reforming [90-91,93-94] and the reduction of $\mathrm{NO}_{x}$ in exhaust gases [85,92]. As said before, diesel soot oxidation in $\mathrm{NO}_{x}$ catalytic traps has been recently proposed as an alternative to simultaneously eliminate $\mathrm{NO}_{\mathrm{x}}$ and particles [95]. Thus, the ceramic catalytic papers could also be applied as structured systems, whose flexibility make them adaptable to different conformations and geometries.

The incorporation of catalysts (single and mixed oxides and zeolites) either during paper manufacturing or after the pressed mat was obtained was studied. The ceramic paper was prepared by a papermaking technique with a dual polyelectrolyte retention system. Considering that wood fibers and fines in an aqueous system are negatively charged due to the ionization of functional groups associated with hemicelluloses, oxidized cellulose and oxidized lignin [85], this method enhances fiber retention. But most important is also the effect of polyelectrolytes in retaining ceramic fibers, catalytic particles and the binder. Different cationic and anionic polymers can be used, the most common ones being PolyDADMAC (cationic polydiallyldimethylammonium chloride), PVAm (cationic 
polyvinyl amine), as cationic polymers and PES-Na (sodium-polyethylenesulphate), C-PAM (cationic polyacrylamide) and A-PAM (anionic polyacrylamide) as anionic polymers.

A ceramic paper to the diesel soot combustion reaction in air, made of ceramic fibers, cerium oxide and potassium nitrate was prepared. The synthesis of this material was easy and fast, and provided a high-temperature resistant paper. The presence of potassium and cerium as active ingredients conferred high catalytic activity for the reaction studied under loose contact, showing a maximum combustion rate at $395^{\circ} \mathrm{C}[20]$.

The results show that the application of the catalytic paper concept is a promising alternative for making catalytic filters to be used in the abatement of diesel contaminants. The fibrous nature of the paper would allow modulating the porosity in order to improve the filtering capacity. The synthesis of the catalytic ceramic paper is easy, fast, and provides a material that can be simply adapted to different conformations and geometries. The presence of potassium and cerium as active ingredients confers a high catalytic activity for the diesel soot combustion reaction under loose contact.

The papermaking technique has also been applied for the preparation of both cellulosic and ceramic papers containing $\mathrm{NaY}$ zeolite, for different uses: those that only contained cellulosic fibers for low temperature applications (cellulosic papers) and those prepared using both cellulosic and ceramic fibers (ceramic papers) for high temperature applications. The first preparations of these zeolitic papers were performed without the addition of binder, and although a decrease in the mechanical properties after calcination was observed, zeolitic ceramic papers resulted easy to handle for practical applications [96]. SEM (Scanning Electron Microscopy) images indicated a good dispersion of zeolite particles within the cellulosic paper whereas in the ceramic paper they appeared anchored on ceramic fibers.

The NaY zeolite resulted homogeneously distributed and the zeolitic cellulosic papers were mechanically acceptable, which makes them promising for applications at low temperatures. In this line, the zeolitic papers prepared resulted efficient as toluene sorbents, the adsorption capacities of zeolitic ceramic papers being higher than those of zeolitic cellulosic papers. Toluene adsorption values demonstrate that zeolite dispersed into the cellulose/ceramic matrix is as effective as powder massive zeolite in retaining the hydrocarbon, which highlights the potential application of these zeolitic structures as sorbent materials both for low and high temperatures. Although a decrease in their mechanical properties was observed due to calcination, zeolitic ceramic papers resulted easy to handle for practical applications.

The purpose of this work is to explore the possibility of using catalytic papers to make efficient self-regenerating diesel soot filters. To this end, different binder components are being employed to enhance the flexibility of ceramic papers; and the amount of ingredients used during the papermaking process is being modified. In this way, paper thickness, catalyst amount, etc, can be varied. Besides, the use of zeolitic ingredients added to the paper constitutes a promising way to generate new and effective SCR structured catalysts. Moreover, the intercalation of paper beds containing different catalysts (sandwich catalysts) could be used for the one-step process to eliminate different contaminants. 


\section{Catalytic tests of powder and structured catalysts}

Peralta et al. studied the optimal parameters for evaluating powder catalysts for the catalytic combustion of soot and they concluded that the best conditions were: a catalyst:soot mass ratio of 20:1 (a mixing time of $6 \mathrm{~min}$ ), a flow rate of $40 \mathrm{ml} / \mathrm{min}$, when loading $10 \mathrm{mg}$ of sample and the oxygen partial pressure was 0.05 bar [97]. The catalysts were evaluated with real soot obtained by diesel combustion in a glass vessel [20] or different materials substitutive of the soot, as carbon black [98] or commercial soot (i.e.: 390127-25G of Aldrich) [99].

To evaluate the performance of structured catalysts, more than one method can be applied. One option is the incorporation of the soot using a suspension of soot in a solvent, for example soot in $n$-hexane $[20,35,52]$ or $n$-heptane [71,76]. In these studies, the soot concentration to incorporate different amounts of soot in the structured catalysts is varied and thus the performance of these structures with different amounts of soot is evaluated. Another option consists in generating a gaseous stream containing soot particles, which can be generated from the burning of diesel fuel $[60,70]$ or by generating a flame from the burning of ethane [100] or acetylene [73] as fuels. On the other hand, previously generated soot particles can be directly dispersed in a gaseous stream, thus generating an aerosol $[26,75,79,101]$.

The filter should be able to trap and burn soot particles as it collects them, so that the filter does not saturate. This is another way of evaluating catalytic activity: to determine the autoregeneration performance of the structured catalysts. This consists in the evaluation of the capacity of burning soot particles from a diesel exhaust as they are trapped in the filter. There are several ways of simulating the diesel exhaust: one consists in collecting one portion of the diesel engine exhausts and to use it to evaluate the performance of the structured catalyst $[72,102,103]$ or simply placing the filter containing the structured catalyst in the diesel engine exhaust [104].

Other variables that can be studied are $\mathrm{O}_{2}$ and $\mathrm{NO}$ concentrations, because these concentrations may change during the operation of the diesel engines and the concentration of these gases is easily varied in the laboratory in an experiment of temperature programmed oxidation.

Another variable that is being studied is the contact between the soot particle and the catalyst. For powder catalysts, mixtures of soot and the catalyst can be prepared by producing either tight or loose contact. In order to check the intrinsic activity of a catalyst so as to determine the best performance of the formulations, tight conditions are preferred [19]. Nevertheless, loose contact represents real conditions so that for structured catalysts, which possess technological applicability, loose contact is preferred to check the performance of the system [52,73].

As structured catalysts can be applied in devices for their use in cars, the adherence of the catalytic coating is fundamental [43]. This stability is studied subjecting the structured catalyst to ultrasonic treatments in different solvents, as acetone $[40,52]$. 
The measurement of the pressure drop during the operation of the diesel particulate filter constitutes a matter of concern, since the catalytic filter should be able to burn soot as it is trapped, so as not to plug the filter. For this purpose, pressure drop versus time is measured and, if the pressure drop increases constantly, the filter cannot burn the trapped soot and finally it becomes obstructed. These measurements depend on the temperature of operation of the filter so that the catalyst should exhibit its best performance in the temperature range of the diesel engine exhausts.

Fino et al. evaluated two catalysts: $\mathrm{LaCr}_{0.9} \mathrm{O}_{3}$ and $\mathrm{Cs}_{2} \mathrm{O}_{2} \mathrm{~V}_{2} \mathrm{O}_{5}$. When these catalysts were tested as powders, they showed a good performance for the catalytic combustion of soot. However, when these catalysts were coated over foam, only the $\mathrm{Cs}_{2} \mathrm{O}_{2} \mathrm{~V}_{2} \mathrm{O}_{5}$ catalyst had an acceptable performance, while the $\mathrm{LaCr}_{0.9} \mathrm{O}_{3}$ catalyst showed a worse performance than that of the uncoated foam. These behaviors were manifested when the structured catalysts were studied under real conditions. In this study, the pressure drop of the foam coated with $\mathrm{LaCr}_{0.9} \mathrm{O}_{3}$ was higher than that observed for the uncoated foam. This indicates that although a system could present good activity as a powder, tests using the structured systems are necessary to discriminate between different formulations [47].

\section{Conclusions}

It can be seen that nowadays the most popular systems for soot elimination in diesel exhausts are a complex combination of different types of physical and chemical processes. More compact processes are highly desirable to reduce costs and improve efficiency. To this end, the synergism between better understandings of the fundamentals of the catalytic reactions together with the development of new structured systems able to efficiently retain soot particles is highly desirable. It has been shown that an adequate morphology of the catalyst is required so as to improve the contact between the catalyst and soot and, simultaneously, the catalyst should be supported as a film on a porous structured substrate, thus allowing simultaneous soot filtration and combustion.

Although monoliths and foams are the most widely studied substrates for the preparation of structured catalysts, other merging substrates that can be considered for controlling the diesel engines exhaust pollutants are ceramic papers and wire meshes. In our laboratory, research works are ongoing, with the aim of developing these types of novel structures in order to make them efficient and economic diesel particulate catalytic filters. In this vein, papers made of ceramic fibers, cerium oxide and potassium nitrate were prepared which provided a high-temperature resistant paper with good activity for soot combustion at temperatures as low as $390^{\circ} \mathrm{C}$. Moreover, the use of zeolitic ingredients added to the paper constituted a new way to generate new and effective SCR structured catalysts. Thus, the intercalation of paper beds containing different catalysts (sandwich catalysts) could be used for the one-step process to simultaneously eliminate soot particles and NOx.

On the other hand, we have developed filters made of AISI-316 stacked wire meshes coated with the $\mathrm{Co}, \mathrm{Ba}, \mathrm{K} / \mathrm{CeO}_{2}$ catalyst, that showed good activity for the combustion of diesel soot. Wire-mesh catalysts combine excellent mass and heat transfer performance with low 
pressure drop, the catalyst efficiency being considerably improved compared with pellet or monolith catalysts. The effects of catalyst clogging and fouling can be handled as these structured catalysts are easy to disassemble and to clean. Wire-mesh catalysts also offer a great flexibility with respect to dimensions that make retrofit installations easier.

\section{Author details}

E.D. Banús, M.A. Ulla, E.E. Miró and V.G. Milt

Instituto de Investigaciones en Catálisis y Petroquímica, INCAPE (FIQ, UNL - CONICET),

Santiago del Estero, Santa Fe, Argentina

\section{Acknowledgement}

The authors wish to acknowledge the financial support received from ANPCyT, CONICET and UNL. Thanks are also given to Elsa Grimaldi for the English language editing.

\section{References}

[1] Twigg M.V. (2011) Catalytic control of emissions from cars. Catal. Today 163: 33-41.

[2] Fino D. (2007) Diesel emission control: Catalytic filters for particulate removal. Sci. Technol. Adv. Mater. 8: 93-100.

[3] Tree D.R., Svensson K.I., (2007) Soot processes in compression ignition engines. Prog. Energy Combust. Sci 33: 272-309.

[4] Gómez-García M. A., Pitchon V., Kiennemann A. (2005) Pollution by nitrogen oxides: an approach to NOx abatement by using sorbing catalytic materials. Environ. Int. 31: 445- 467.

[5] Lu X., Han D., Huang Z. (2011) Fuel design and management for the control of advanced compression-ignition combustion modes. Prog. Energy. Combust. Sci. 37 (2011) 741-783.

[6] Gan S., Ng H.K., Pang K.M. (2011) Homogeneous Charge Compression Ignition (HCCI) combustion: Implementation and effects on pollutants in direct injection diesel engines. Appl. Energ. 88 (2011) 559-567.

[7] Neeft J.P.A., Schipper, W., Mul, G., Makkee M. Moulijn, J.A. (1997) Feasibility study towards a $\mathrm{Cu} / \mathrm{K} / \mathrm{Mo} /(\mathrm{Cl})$ soot oxidation catalyst for application in diesel exhaust gases. Appl. Catal. B: Environmental 11, 365.

[8] Twigg M.V. (2007) Progress and future challenges in controlling automotive exhaust gas emissions. Appl. Catal. B: Environmental 70, 2-15.

[9] Heck R.M., Farrauto R.J. (2001) Automobile exhaust catalysts. Appl. Catal. A: General, 221, 443-457.

[10] http://www1.eere.energy.gov/vehiclesandfuels/pdfs/deer_2002/session11/2002_deer_ch atterjee1.pdf

${ }^{*}$ Corresponding Author 
[11] Stanmore B.R., Tschamber V., Brilhac, J.F. (2007) Oxidation of carbon by NOx, with particular reference to $\mathrm{NO}_{2}$ and $\mathrm{N}_{2} \mathrm{O}$. Fuel, 87: 131-146.

[12] Krishna K., Makkee, M. (2006) Soot oxidation over NOx storage catalysts: Activity and deactivation. Catal. Today 114: 48-56.

[13] Milt V.G., Querini, C.A., Miró, E.E., Ulla, M.A. (2003) Abatement of diesel exhaust pollutants: NOx adsorption on $\mathrm{Co}, \mathrm{Ba}, \mathrm{K} / \mathrm{CeO}_{2}$ catalysts. J. Catal. 220: 424-432.

[14] Nakatani, K., Hirota, S., Takeshima, S., Itoh, K., Tanaka, T. (2002) Simultaneous PM and $\mathrm{NO}_{x}$ Reduction System for Diesel Engines. SAE paper 2002-01-0957.

[15] Itoh, K., Tanaka, T., Hirota, S., Asanuma, T., Kimura, K., Nakatani, K. (2003) Exhaust purifying method and apparatus of an internal combustion engines. US patent, US $6,594,991$.

[16] Sullivan J.A., Keane O., Cassidy A. (2007) Beneficial and problematic interactions between $\mathrm{NO}_{x}$ trapping materials and carbonaceous particulate matter. Appl. Catal. B: Environmental 75: 102-106

[17] Peralta M.A., Zanuttini M.S., Querini C.A. (2011) Activity and stability of $\mathrm{BaKCo} / \mathrm{CeO}_{2}$ catalysts for diesel soot oxidation. Appl. Catal. B: Environmental 110: 90- 98.

[18] Lim C.B., Kusaba H., Einaga H., Teraoka Y. (2011) Catalytic performance of supported precious metal catalysts for the combustion of diesel particulate matter. Catal. Today 175: 106-111.

[19] Sun M., Wang L., Feng B., Zhang Z., Lu G., Guo Y. (2011) The role of potassium in $\mathrm{K} / \mathrm{Co}_{3} \mathrm{O}_{4}$ for soot combustion under loose contact. Catal. Today 175: 100-105.

[20] Banús E.D., Ulla M.A., Galván M.V., Zanuttini M.A., Milt V.G., Miró E.E. (2010) Catalytic ceramic paper for the combustion of diesel soot. Catal. Comm. 12: 46-49.

[21] Azambre B., Collura S., Darcy P., Trichard J.M., Da Costa P., García-García A., BuenoLópez A. (2011) Effects of a $\mathrm{Pt} / \mathrm{Ce} 0.68 \mathrm{Zr}_{0.32} \mathrm{O}_{2}$ catalyst and $\mathrm{NO}_{2}$ on the kinetics of diesel soot oxidation from thermogravimetric analyses. Fuel Process Technol 92: 363-371.

[22] Wang Z., Li Q., Wang L., Shangguan W. (2012) Simultaneous catalytic removal of NOx and soot particulates over CuMgAl hydrotalcites derived mixed metal oxides. Appl. Clay Sci. 55: 125-130.

[23] Li Q. ,Meng M., Xian H., Tsubaki N., Li X., Xie Y., Hu T., Zhang J. (2010) HydrotalciteDerived $\mathrm{Mn}_{x} \mathrm{Mg}_{3-\mathrm{x}} \mathrm{AlO}$ Catalysts Used for Soot Combustion, NOx Storage and Simultaneous Soot-NOx Removal. Environ. Sci. Technol. 44: 4747-4752.

[24] Zawadzki M., Staszak W., López-Suárez F.E., Illán-Gómez M.J., Bueno-López, A. (2009) Preparation, characterisation and catalytic performance for soot oxidation of coppercontaining $\mathrm{ZnAl}_{2} \mathrm{O}_{4}$ spinels. Appl. Catal. A: General 371: 92-98.

[25] Zawadzki M., Walerczyk W., López-Suárez F.E., Illán-Gómez M.J., Bueno-López A. (2011) $\mathrm{CoAl}_{2} \mathrm{O}_{4}$ spinel catalyst for soot combustion with $\mathrm{NO}_{x} / \mathrm{O}_{2}$. Catal. Commun. 12: 1238-1241.

[26] Li S., Kato R., Wang Q., Yamanaka T., Takeguchi T., Ueda W. (2010) Soot trapping and combustion on nanofibrous perovskite $\mathrm{LaMnO}_{3}$ catalysts under a continuous flow of soot. Appl. Catal. B: Environmental 93: 383-386. 
[27] Li Z., Meng M., Dai F., Hu T., Xie Y., Zhang J. (2012) Performance of K and Ni substituted $\mathrm{La}_{1-\mathrm{x}} \mathrm{K}_{\mathrm{x}} \mathrm{Co}_{1-\mathrm{y}} \mathrm{Ni}_{\mathrm{y}} \mathrm{O}_{3-\delta}$ perovskite catalysts used for soot combustion, $\mathrm{NO}_{x}$ storage and simultaneous $\mathrm{NO}_{x}$-soot removal. Fuel 93: 606-610.

[28] Li Z., Meng M., Li Q., Xie Y., Hu T., Zhang J. (2010) Fe-substituted nanometric La0.9 $\mathrm{K}_{0.1} \mathrm{CO}_{1-x} \mathrm{Fe}_{\times} \mathrm{O}_{3-\delta}$ perovskite catalysts used for soot combustion, $\mathrm{NO}_{x}$ storage and simultaneous catalytic removal of soot and NOx. Chem. Eng. J. 164: 98-105.

[29] Milt V.G., Ulla M.A., Miró E.E. (2005) NOx trapping and soot combustion on $\mathrm{BaCoO}_{3-\mathrm{y}}$ perovskite: LRS and FTIR characterization. Appl. Catal. B: Environmental 57: 13-21.

[30] Muroyama H., Hano S., Matsui T., Eguchi K. (2010) Catalytic soot combustion over $\mathrm{CeO}_{2}$-based oxides. Catal. Today 153: 133-135.

[31] Zhang R., Luo N., Chen B., Kaliaguine S. (2010) Soot Combustion over Lanthanum Cobaltites and Related Oxides for Diesel Exhaust Treatment. Energy Fuels 24: 37193726.

[32] Milt V.G., Banús E.D., Ulla M.A., Miró E.E. (2008) Soot combustion and NOx adsorption on $\mathrm{Co}, \mathrm{Ba}, \mathrm{K} / \mathrm{ZrO}_{2}$. Catal Today 133-135: 435-440.

[33] Colombo M., Nova I., Tronconi E., Schmeißer V., Bandl-Konradb B., Zimmermann L. (2012) $\mathrm{NO} / \mathrm{NO}_{2} / \mathrm{N}_{2} \mathrm{O}-\mathrm{NH}_{3} \mathrm{SCR}$ reactions over a commercial Fe-zeolite catalyst for diesel exhaust aftertreatment: Intrinsic kinetics and monolith converter modeling. Appl. Catal. B: Environmental 111-112: 106-118.

[34] Colombo M., Nova I., Tronconi E. (2012) $\mathrm{NO}_{2}$ adsorption on Fe- and Cu-zeolite catalysts: The effect of the catalyst red-ox state. Appl. Catal. B: Environmental 111-112: 433- 444.

[35] Shan W., Liu F., He H., Shi X., Zhang C. (2012) An environmentally-benign $\mathrm{CeO}_{2}-\mathrm{TiO}_{2}$ catalyst for the selective catalytic reduction of $\mathrm{NO}_{x}$ with $\mathrm{NH}_{3}$ in simulated diesel exhaust. Catal. Today, in press.

[36] Shan W., Liu F., He H., Shi X., Zhang C. (2012) A superior Ce-W-Ti mixed oxide catalyst for the selective catalytic reduction of $\mathrm{NO}_{x}$ with $\mathrm{NH}_{3}$. Appl. Catal. B: Environmental 115-116: 100-106.

[37] Koga H., Kitaoka T. (2011) One-step synthesis of gold nanocatalysts on a microstructured paper matrix for the reduction of 4-nitrophenol. Chem. Eng. J. 168: $420-425$.

[38] Meille V. (2006) Review on methods to deposit catalysts on structured surfaces. Appl. Catal. A: General 315: 1-17.

[39] Konstandopoulosa A.G., Kostogloua M. (2000) Reciprocating flow regeneration of soot filters. Comb. Flame, 121: 488-500.

[40] Yang K.S., Mul G., Choi J.S., Moulijn J.A., Chung J.S. (2006) Development of $\mathrm{TiO}_{2} / \mathrm{Ti}$ wire-mesh honeycomb for catalytic combustion of ethyl acetate in air. Appl. Catal. A: General 313: 86-93.

[41] Ahlström-Silversand A.F., Ingemar Odenbrand C.U., (1997) Thermally sprayed wiremesh catalysts for the purification of flue gases from small-scale combustion of bio-fuel Catalyst preparation and activity studies. Appl. Catal. A: General 153: 177-201. 
[42] Banús E.D., Milt V.G., Miró E.E., Ulla M. A. (2012) Catalytic coating synthesized onto cordierite monolith walls. Its application to Diesel soot combustion. Appl. Catalysis B: Environmental, submitted.

[43] Banús E.D., Milt V.G., Miró E.E., Ulla M.A. (2010) Co,Ba, $\mathrm{K} / \mathrm{ZrO}_{2}$ coated onto metallic foam (AISI 314) as a structured catalyst for soot combustion: Coating preparation and characterization. Appl. Catal. A: General 379: 95-104.

[44] Heck R.M., Gulati S., Farrauto R.J. (2001) The application of monoliths for gas phase catalytic reactions. Chem. Eng. J. 82: 149-156.

[45] http://www.ikts.fraunhofer.de/en/Images/WabeExtruder_2_tcm244-32344.JPG.

[46] http://www.corning.com/WorkArea/showcontent.aspx?id=6465.

[47] Biamino S., Fino P., Fino D., Russo N., Badini C. (2005) Catalyzed traps for diesel soot abatement: In situ processing and deposition of perovskite catalyst. Appl. Catal. B: Environmental 61: 297-305.

[48] Cauda E., Fino D., Saracco G., Specchia V. (2004) Nanosized Pt-perovskite catalyst for the regeneration of a wall-flow filter for soot removal from diesel exhaust gases. Top. Catal. 30/31: 299-303.

[49] Fino D., Cauda E., Mescia D., Russo, Saracco G., Specchia V. (2007) $\mathrm{LiCoO}_{2}$ catalyst for diesel particulate abatement. Catal. Today 119: 257-261.

[50] Cauda E., Mescia D., Fino D., Saracco G., Specchia V. (2005) Diesel Particulate Filtration and Combustion in a Wall-Flow Trap Hosting a $\mathrm{LiCrO}_{2}$ Catalyst. Ind. Eng. Chem. Res. 44: 9549-9555.

[51] Fino D., Fino P., Saracco G., Specchia V. (2003) Innovative means for the catalytic regeneration of particulate traps for diesel exhaust cleaning. Chem. Eng. Sci. 58: 951 958.

[52] Neeft J.P.A., van Pruissen O.P., Makkee M., Moulijn J.A. (1997) Catalysts for the oxidation of soot from diesel exhaust gases II. Contact between soot and catalyst under practical conditions. Appl. Catal. B: Environmental 12: 21-31.

[53] Neyertz C.A., Miró E.E. Querini C.A. (2012) $\mathrm{K} / \mathrm{CeO}_{2}$ catalysts supported on cordierite monoliths: Diesel soot combustion study. Chem. Eng. J. 181-182: 93-102.

[54] Gálvez M.E., Ascaso S., Tobías I., Moliner R., Lázaro M.J. (2012) Catalytic filters for the simultaneous removal of soot and NOx: Influence of the alumina precursor on monolith washcoating and catalytic activity. Catal. Today 191: 96-105.

[55] Gálvez M.E., Ascaso S., Moliner R., Jiménez R., García X., Gordon A., Lázaro M.J. (2011) Catalytic filters for the simultaneous removal of soot and $\mathrm{NO}_{x}$ : Effect of $\mathrm{CO}_{2}$ and steam on the exhaust gas of diesel engines. Catal. Today 176: 134-138.

[56] Bortolozzi J.P., Banús E.D., Milt V.G., Gutierrez L.B., Ulla M.A. (2010) The significance of passivation treatments on AISI 314 foam pieces to be used as substrates for catalytic applications. Appl. Surf. Sci. 257: 495-502.

[57] Raj R.E., Parameswaran V., Daniel B.S.S. (2009) Comparison of quasi-static and dynamic compression behavior of closed-cell aluminum foam. Mat. Sci. Eng. A 526: 11-15. 
[58] Kurtbas I., Celik N. (2009) Experimental investigation of forced and mixed convection heat transfer in a foam-filled horizontal rectangular channel Original. Int. J. Heat Mass Transfer 52: 1313-1325.

[59] Twigg M.V., Richardson J.T. (2002) Theory and applications of ceramic foam catalysts. Chem. Eng. Research. Design, 80: 183-189.

[60] Banús E.D., Milt V.G., Miró E.E., Ulla M.A. (2009) Structured catalyst for the catalytic combustion of soot: $\mathrm{Co}, \mathrm{Ba}, \mathrm{K} / \mathrm{ZrO}_{2}$ supported on $\mathrm{Al}_{2} \mathrm{O}_{3}$ foam. Appl. Catal. A: General 362: 129-138.

[61] Nor M.A.A.M., Hong L.C., Ahmad Z.A., Akil H.M. (2008) Preparation and characterization of ceramic foam produced via polymeric foam replication method. J. Mat. Process. Tech. 207: 235-239.

[62] Silva S.A., Brunelli D.D., Melo F.C.L., Thim G.P. (2009) Preparation of a reticulated ceramic using vegetal sponge as templating. Ceramic. Int. 35: 1575-1579.

[63] Mao X., Wang S., Shimai S., (2008) Porous ceramics with tri-modal pores prepared by foaming and starch consolidation. 34: 107-112.

[64] Yu J., Sun X., Li Q., Li, X. (2008) Preparation of $\mathrm{Al}_{2} \mathrm{O}_{3}$ and $\mathrm{Al}_{2} \mathrm{O}_{3}-\mathrm{ZrO}_{2}$ ceramic foams with adjustable cell structure by centrifugal slip casting. Mat. Sci. Eng. A 476: 274-280.

[65] He X., Zhou X., Su B. (2009) 3D interconnective porous alumina ceramics via direct protein foaming. Mater. Lett. 65: 830-832.

[66] Barg S., Soltmann C., Andrade M., Kock D., Grathwohl G. (2008) Cellular Ceramics by Direct Foaming of Emulsified Ceramic Powder Suspensions. J. Am. Cerm. Soc. 91: 28232829.

[67] Ashby M.F., Evans A.G., Fleck N.A., Gibson L.J., Hutchinson J.W., Wadley H.N.G., Metal Foams: A Desing Guide. Butterworth-Heinemann. 2000. United States of America.

[68] Ciambelli P., Palma V., Russo P., Vaccaro S. (2002) Deep filtration and catalytic oxidation: an effective way for soot removal. Catal. Today 73: 363-370.

[69] Russo P., Ciambelli P., Palma V., Vaccaro (2003) Simultaneous Filtration and Catalytic Oxidation of Carbonaceous Particulates. Top. Catal 22: 123-129.

[70] Ciambelli P., Palma V., Russo P., Vaccaro S. (2002) Performances of a catalytic foam trap for soot abatement. Catal. Today 75: 471-478.

[71] Ciambelli P., Palma V., Russo P., Vaccaro S. (2005) Issues on soot removal from exhaust gases by means of radial flow ceramic traps. Chem. Eng. Sci. 60: 1619-1627.

[72] Palma V., P. Russo, M. D'Amore, P. Ciambelli (2004) Microwave regenerated catalytic foam: a more effective way for PM reduction. Top. Catal. 30/31: 261-264.

[73] Saracco G., Badini C., Russo N., Specchia V. (1999) Development of catalysts based on pyrovanadates for diesel soot combustion. Appl. Catal. B: Environmental 21: 233-242.

[74] Setiabudi A., van Setten B.A.A.L., Makkee M., Moulijn J.A. (2002) The influence of NOx on soot oxidation rate: molten salt versus platinum. Appl. Catal. B: Environmental 35: 159-166. 
[75] Ambrogio M., Saracco G., Specchia V. (2001) Combining filtration and catalytic combustion in particulate traps for diesel exhaust treatment. Chem. Eng. Sci. 56: 16131621.

[76] Saracco G., Russo N., Ambrogio M., Badini C., Specchia V. (2000) Diesel particulate abatement via catalytic traps. Catal. Today 60: 33-41.

[77] Ciambelli P., Corbo P., Palma V., Russo P., Vaccaro S., Vaglieco B. (2001) Study of Catalytic Filters for Soot Particulate Removal from Exhaust Gases. Top. Catalysis 16-17: 279-284.

[78] Caglar B., Üner D. (2007) Preparation and Morphological Characterization of a Catalytic Soot Oxidation SiC Foam Filter. Turkish J. Chem. 31: 487-492.

[79] van Setten B.A.A.L., Bremmer J., Jelles S.J., Makkee M., Moulijn J.A. (1999) Ceramic foam as a potential molten salt oxidation catalyst support in the removal of soot from diesel exhaust gas. Catal. Today 53: 613-621.

[80] van Setten B.A.A.L., van Gulijk C., Makkee M., Moulijn J.A. (2001) Molten Salts Are Promising Catalysts. How to Apply in Practice? Top. Catal. 16/17: 275-278.

[81] Ciambelli P., Matarazzo G., Palma V., Russo P., Merlone Borla E., Pidria M.F. (2007) Reduction of soot pollution from automotive diesel engine by ceramic foam catalytic filter. Top. Catal. 42-43: 287-291.

[82] E. Bruneel, J. Van Brabant, M.T. Le, I. Van Driessche (2012) Deposition of a Cu/Mo/Ce catalyst for diesel soot oxidation on a sintered metal fiber filter with a $\mathrm{CeO}_{2}$ anti corrosion coating, Catal Comm., in press.

[83] Walther G., Klöden B., Büttner T., Weißgärber T., Kieback B., Böhm A., Naumann D., Saberi S., Timberg L. (2008) A New Class of High Temperature and Corrosion Resistant Nickel-Based Open-Cell Foams. Adv. Eng. Mater. 10: 803-811.

[84] Kwon H.J., Kim Y., Nam I., Jung S.M., Lee J. (2010) The Hydrothermal Stability of Paper-Like Ceramic Fiber and Conventional Honeycomb-Type Cordierite Substrates Washcoated with $\mathrm{Cu}-\mathrm{MFI}$ and $\mathrm{V}_{2} \mathrm{O}_{5} / \mathrm{TiO}_{2}$ Catalysts for the Selective Reduction of $\mathrm{NO}_{x}$ by $\mathrm{NH}_{3}$. Top. Catal. 53: 439-446.

[85] Bhardwaj N., Hoang V., Nguyen K.L. (2007) Effect of refining on pulp surface charge accessible to polydadmac and FTIR characteristic bands of high yield kraft fibres. Biores. Technol. 98: 962-966.

[86] Ichiura H., Kitaoka T., Tanaka H. (2003) Removal of indoor pollutants under UV irradiation by a composite $\mathrm{TiO}_{2}$-zeolite sheet prepared using a papermaking technique. Chemosphere 50: 79-83.

[87] Ichiura H., Kitaoka T., Tanaka H. (2002) Preparation of composite $\mathrm{TiO}_{2}$-zeolite sheets using a papermaking technique and their application to environmental improvement: Part I Removal of acetaldehyde with and without UV irradiation. J. Mater. Sci. 37: 29372941.

[88] Koga H., Ishihara H., Kitaoka T., Tomoda A., Suzuki R., H. Wariishi (2010) The Hydrothermal Stability of Paper-Like Ceramic Fiber and Conventional HoneycombType Cordierite Substrates Washcoated with $\mathrm{Cu}-\mathrm{MFI}$ and $\mathrm{V}_{2} \mathrm{O}_{5} / \mathrm{TiO}_{2}$ Catalysts for the Selective Reduction of $\mathrm{NO}_{x}$ by $\mathrm{NH}_{3}$. J. Mat. Sci. 45: 4151-4157. 
[89] Koga H., Umemura Y., Ishihara H., Kitaoka T., Tomoda A., Suzuki R., Wariishi H. (2009) Paper-structured fiber composites impregnated with platinum nanoparticles synthesized on a carbon fiber matrix for catalytic reduction of nitrogen oxides. Appl. Catal. B: Environmental 90: 699-704.

[90] Fukahori S., Kitaoka T., Tomoda A., Suzuki R., Warrishi H. (2006) Methanol steam reforming over paper-like composites of $\mathrm{Cu} / \mathrm{ZnO}$ catalyst and ceramic fiber. Appl. Catal. A: General 300: 155-161.

[91] Koga H., Fukahori S., Kiyaoka T., Tomoda A., Suzuki R., Wariishi H. (2006) Autothermal reforming of methanol using paper-like $\mathrm{Cu} / \mathrm{ZnO}$ catalyst composites prepared by a papermaking technique. Appl. Catal. A: General 309: 263-269.

[92] Koga H., Ishihara H., Kitaoka T., Tomoda A., Suzuki R., Wariishi H. (2010) NOx reduction over paper-structured fiber composites impregnated with $\mathrm{Pt} / \mathrm{Al}_{2} \mathrm{O}_{3}$ catalyst for exhaust gas purification. J. Mater. Sci. 45: 4151-4157.

[93] Koga H., Fukahori S., Kitaoka T., Nakamura M., Wariishi H. (2008) Paper-structured catalyst with porous fiber-network microstructure for autothermal hydrogen production. Chem. Eng. J. 139: 408-415.

[94] Fukahori S., Koga H., Kitaoka T., Tomoda A., Suzuki R., Wariishi H. (2006) Hydrogen production from methanol using a $\mathrm{SiC}$ fiber-containing paper composite impregnated with $\mathrm{Cu} / \mathrm{ZnO}$ catalyst. Appl. Catal. A: General 310: 138-144.

[95] Krishna K., Makkee M. (2006) Soot oxidation over NOx storage catalysts: Activity and deactivation. Catal. Today 114: 48-56.

[96] Cecchini J.P., Serra R.M., Barrientos C.M., Ulla M.A., Galván M.V., Milt V.G. (2011) Ceramic papers containing Y zeolite for toluene removal. Micropor. Mesopor. Mat. 145: 51-58.

[97] López-Fonseca R., Landa I., Elizundia U., Gutiérrez-Ortiz M.A., González-Velasco J.R. (2007) A kinetic study of the combustion of porous synthetic soot. Chem. Eng. J. 129: 4149.

[98] Nhon Y.N.H., Magan H.M., Petit C. (2004) Catalytic diesel particulate filter evaluation of parameters for laboratory studies. Appl. Catal. B: Environmental 49: 127-133.

[99] Peralta M.A., Gross M.S., Sánchez B.S., Querini C.A. (2009) Catalytic combustion of diesel soot: Experimental design for laboratory testing. Chem. Eng. J. 152: 234-241.

[100] Lizarraga L., Souentie S., Boreave A., George S.C., D’Anna B., Vernoux P. (2011) Effect of Diesel Oxidation Catalysts on the Diesel Particulate Filter Regeneration Process. Environ. Sci.Technol. 45: 10591-10597.

[101] Tanthapanichakoon W., Charinpanitkul T. (2012) Suppression of fugitive dust emitted from stone quarrying process using wetted wire screen. Sep. Purif. Technol. 92: 17-20.

[102] Caroca J.C., Millo F., Vezza D., Vlachos T., De Filippo A., Bensaid S., Russo N., Fino D. (2011) Detailed Investigation on Soot Particle Size Distribution during DPF Regeneration, using Standard and Bio-Diesel Fuels. Ind. Eng. Chem. Res. 50: 2650-2658.

[103] Bensaid S., Russo N. (2011) Low temperature DPF regeneration by delafossite catalysts. Catal. Today 176: 417- 423. 
[104] Silva R.F., De Oliveira E., de Sousa Filho P.C., Neri C.R., Serra O.A. (2011) Diesel/biodiesel soot oxidation with $\mathrm{CeO}_{2}$ and $\mathrm{CeO}_{2}-\mathrm{ZrO}_{2}$-modified cordierites: a facile way of accounting for their catalytic ability in fuel combustion processes. Quimica Nova, 34: 759-763.

[105] www.dieselnet.com/tech/engine_control.html. 